\title{
1 \\ Provincialising the State: Symbiotic Nature and Survival Politics in Post-World War Zero Japan
}

\author{
Sho Konishi
}

This chapter explores the idea and practice of what I have called elsewhere 'cooperatist anarchist modernity'. It looks at one particular moment in the long historical development of this vision and practice of progress, the period following the Russo-Japanese War of 1904-05, when an anarchist scientific turn occurred. Some historians have called this war 'World War Zero', in reference to its status as the first of the modern, all-encompassing global wars of the 20th century. ${ }^{1}$ The scientific turn in the wake of the war was integral to the dynamic development of anarchism in Japan and would in turn generate a wave of innovative thought and cultural practices. By introducing the popularised notion of symbiotic nature as the driver of evolution and civilisational progress ${ }^{2}$ and its temporality in post RussoJapanese War Japan, this chapter demonstrates the cooperatist anarchist cultural overturning of the idea and practice of progress fashioned after

1 John Steinberg, Bruce W. Menning, David Schimmelpenninck van der Oye, David Wolff, and Shinji Yokote eds, The Russo-Japanese War in Global Perspective: World War Zero (Leiden: Brill, 2005), 349-64.

2 The notion of 'symbiotic nature' contrasted with the Darwinist notion of competition as the source of progress and natural evolution. 
the West that provincialised the state. ${ }^{3}$ This historic overcoming of Western modernity served as the epistemological and cultural foundation of survival politics of the everyday, an understanding from which contemporary informal life politics may be meaningfully discussed and discerned. The chapter reveals not what ordinary people did on the main floor of shops and institutions during the day, but what they did upstairs at night. We will visit public intellectuals not at their imperial universities, but when they gathered in the evenings on the second floor of a sweet shop or a people's hospital after closing time. Then I would like to introduce a place 50 miles from nowhere on the northernmost island of Hokkaido in order to talk about ordinary farmers who, I argue, consciously adopted and put into practice the concept of cooperatist anarchist progress and thereby conceived of themselves as standing at the forefront of modern progress and civilisation. In doing so, these former tenant farmers, overcoming tremendous fear, managed to survive liberation from tenancy in the most severe living conditions.

In 1906, less than a year after the Portsmouth Treaty that ended the RussoJapanese War, two of the most popular writers in late Meiji-Taisho Japan, Tokutomi Roka and Arishima Takeo (who was then in America), made separate pilgrimages to the homes of figures that they saw as symbols of international peace, civilisation and progress. Both traced the major sites of inspiration for human civilisational development, and culminated their respective travels at the homes of Russian anarchist thinkers, Peter Kropotkin and Lev Tolstoy. It was in the immediate post-war period that the faces of Tolstoy and Kropotkin, symbols of the Japanese Nonwar Movement in the Russo-Japanese War, appeared arm-in-arm on the Japanese cultural scene, to the point that we might call it a phenomenon of Tolstoy-Kropotkinism. It would be difficult to read the public prominence of these particular figures without an understanding of anarchism and its provincialising of the nation-state in early 20th-century Japan.

After winning the Russo-Japanese War, people in Japan had an unprecedented opportunity to engage with the wider world afresh. And the 'world' was watching with great anticipation to see what the people of Japan would bring to the world. It is hardly a coincidence that some

3 This anarchist notion of 'provincialising the state' may be contrasted with that of Dipesh Chakrabarty's 'provincialising Europe', which focuses on indigenous sources of modern state- and nation-building. Dipesh Chakrabarty, Provincializing Europe: Postcolonial Thought and Historical Difference (Princeton, NJ: Princeton University Press, 2000). 
historians begin the history of decolonisation movements from 1905 because of the perceived significance of the war for the colonised world. Our historiography has given only one historical meaning to this war for Japanese history in the wider world: Japan's entry into the group of elite civilised sovereign nation-states and its embarkation onto the path of Western modernity. At the time, however, a number of people in fact came to share a very different view of the war, that it represented a retrogression of human progress. Their view of world order was also ideologically opposed to the most basic assumptions of the rising decolonisation movements. Decolonisation movements were political movements that sought to liberate the nation from imperialism, by transferring power to indigenous hands in order to found a sovereign nation-state modelled after the West. ${ }^{4}$ Yet in the Japanese Nonwar Movement's imagination of free transnational, non-state relations among 'people' around the world was an ideology of emancipation from that very territorial utopia of Western modernity founded on the modern nation-state.

I suggest that the war served as a pivotal experience that made salient a deep conflict between competing visions of human progress and civilisation. The view of the Nonwar Movement, probably the most successful peace movement in a time of war in modern history as scholar Hyman Kublin has suggested, ${ }^{5}$ sharply contrasted with the ideology of Western modernity that sanctioned, if not celebrated, Japan's entry into the community of nation-states as a result of its victory in war and empire building. The experience of the war only helped to solidify a cooperatist anarchist historical consciousness that would take the form of social action. Historians have long overlooked this vision and corresponding practices, which did not fit the narrative of Western modernity ('History'). 'History' has been that familiar narrative of the rise and development of the nationstate toward a Western modern form of political and economic liberty, or Hegelian Reason. Japan has been narrated according to this History as 'late'.

\footnotetext{
4 Prasenjit Duara, 'Introduction: The Decolonisation of Asia and Africa in the Twentieth Century', in Prasenjit Duara ed., Decolonisation: Perspectives From Now and Then (London: Routledge, 2004), $1-20$.

5 Hyman Kublin, 'The Japanese Socialists and the Russo-Japanese War', Journal of Modern History 21 (March-December 1950): 322-39.

6 On the conceptualisation of the war as a retrogression of civilisation and development by the Nonwar Movement, see Konishi, 'The Absence of Portsmouth in an Early Twentieth-Century Imagination of Peace', in Steven J. Ericson, Allen Hockley, The Treaty of Portsmouth and Its Legacies (Hanover and London: University Press of New England, 2008), 98-105.
} 
I argue that in the immediate aftermath of the war, what I call a 'history slide', (rekishi no jisuberi 歴史の地滑り) occurred, a slide of historical consciousness that produced a reconceived subjectivity of the present as a point of moral action in the here and now to attain that new future. Nonwar participants perceived their location in the given space and time as backward. The present as a product of Western progress was now perceived as behind and no longer morally justifiable. History thus slid from narratives of the past to justify the present to a narrated future vision. In what would develop into an anarchist theory of social change, the 'present' had become the urgent moment to rectify history for the future. As Arishima wrote in 1905, history was to be 'kiyome tadasu' (morally cleansed and rectified 清女正す). Inferiority was now assigned not to a given space but to a belonging to a certain sense of time or temporality.

Certainly, among the supporters of the Nonwar Movement, neither the Portsmouth Peace Treaty nor the Nobel Peace Prize consequently awarded to Theodore Roosevelt for brokering that treaty was a part of their discussions of peace. One could even say that members of the movement were completely disinterested in the peacemaking achievements of the international community in ending the war between Russia and Japan. Despite the participants' seeming reticence in relation to the international community and its territorial utopia of Western modernity, the Nonwar Movement's ideological redrawing of the concept of peace attracted many people in Japan.

I chose to translate the term Japanese participants used for their movement, hisen undō 非戦運動, as 'Nonwar Movement'. References to the movement have translated hisen undō as 'Antiwar Movement', without distinguishing it from the more contemporary Japanese term hansen undō 反戦運動. This translation not only fails to reflect the intellectual universe of the movement, but may be misleading, for the term hansen as it has been used in the post-Asia-Pacific War period refers to an oppositional position against a particular war, as in the Antiwar Movement in America during the Vietnam War. At the same time, the hisen undō of the RussoJapanese War did not express a philosophical position of pacifism, the total negation of violence.

In fact, hisen was a term historically specific to the Russo-Japanese War, with the war being the only time that the term would ever be used. Inherent in the language of hisen was a construct of civilisation and progress that was distinguished from Western modernity. According 
to their construct, imperialist wars were not a part of that modernity, and therefore hi, 'absent'. We may thereby conceive this movement as an intellectual phenomenon for a given understanding of progress and civilisation, rather than against a particular war or against violence on absolute terms.

\section{Anarchist Science}

In this context of wide-ranging questioning of the progressiveness of Western modernity following the war, science became the vessel through which the 'true nature' of human behaviour and society could be discerned. In my view, the end of the war simultaneously marked what may be called a scientific turn. The anarchist Ōsugi Sakae was emblematic of this turn. He developed a deep interest in scientific knowledge of astronomy, evolutionary biology and animal behaviour that in turn inspired him to realise that he was an 'anarchist' at this time.

Ōsugi made a direct link between human society and the centreless nature of the universe and claimed that the interdependent relationship between humans and nature was such that it logically followed that humans had no choice but to harmonise society with the most advanced scientific knowledge of space matter and the natural world. This devotion to scientific knowledge that was selectively interpreted by anarchists to represent the future of human society is what I call 'anarchist science'? Ōsugi believed that human subjectivity and social relations ought to reflexively mirror scientific findings about the nature and 'logic' of the physical and natural universe around and within human beings. This perspective on the human world rooted in a scientific view of the logic and functioning of nature and biological evolution helped inspire a new wave of Japanese interest in anarchism after the war. The definitive postwar moment of the history slide when anarchist ideas of progress were adopted was accompanied by this scientific turn.

7 Sho Konishi, 'The Science of Symbiosis and Linguistic Democracy in Early Twentieth-Century Japan', Interdisciplinary Description of Complex Systems (INDEKS) 13, no. 2 (2015): 299-317. See also Sho Konishi, Anarchist Modernity: Cooperatism and Japanese-Russian Intellectual Relations in Modern Japan (Cambridge, Mass.: Harvard University Press, 2013), 296-327. 
Ōsugi was certainly not the only one to develop a deep interest in natural science immediately following the war. During his transnational pilgrimage to Kropotkin's home, Arishima held on to one book, written by the Russian embryologist and microbiologist Ilia Mechnikov, who would win the Nobel Prize for his work on micro-organisms and immunity in $1908 .{ }^{8}$ It is curious that at this critical moment immediately after the war, Arishima chose to read, not revolutionary texts of revolt or texts on international relations, but a text by a Russian microbiologist. How can one possibly grasp the place of micro-organisms in the embrace of anarchism in this period? In the broader context of war and imperialist expansion, terrorism and assassination by anarchists worldwide, and government persecution of anarchists and socialists, anarchists in Japan like Arishima turned to Mechnikov's universe of bacteria and phagocytes and, later, the spiders, dung beetles and wasps of the French entomologist Jean Henri Fabre, in their search for answers to the world problems at hand. If Theodore Roosevelt and the Nobel Peace Prize of $1906 \mathrm{did}$ not represent their idea of peace, then certainly the Nobel Prize in science awarded to Mechnikov two years later represented perfectly their idea of peace and civilisational progress.

Kōtoku Shūsui, a theoretical leader of anarchism and the Nonwar Movement, echoed the notion of the centreless universe. In his introduction to Darwin's theory that helped popularise ideas of evolution in Japan, Kōtoku wrote that after Charles Darwin, 'there will be no more debate about the beginningless and endless composition of nature'.? Japanese anarchists embraced what astronomer Mark Davis characterises today as 'negative discovery', the understanding:

That Earth is not the center of the Universe.

That the Sun is not the center of the Universe.

Our galaxy is not the center of the Universe.

Our type of matter is not the dominant constituent of the Universe (dark matter predominates instead).

Our Universe (seen and unseen) is not the only Universe. ${ }^{10}$

8 On Mechnikov's work on immunology, see Alfred I. Tauber and Leon Chernyak, Metchnikoff and the Origins of Immunology: From Metaphor to Theory (New York, Oxford: Oxford University Press, 1991).

9 'Dāwin to Marukusu' [Darwin and Marx], Heimin shimbun 47 (2 October 1904): 5.

10 Davis is quoted in Daniel Boorstin, Cleopatra's Nose: Essays on the Unexpected (New York: Vintage Press, 1995), 7. 
The centre of the universe was scattered everywhere and nowhere at the same time. Kropotkin expressed this idea in his work Anarchism:

It is to this dust, to these infinitely tiny bodies that dash through space in all directions with giddy swiftness, that clash with one another, agglomerate, disintegrate, everywhere and always, it is to them that today astronomers look for an explanation of the origin of our solar system, the movements that animate its parts, and the harmony of their whole ... Thus the center, the origin of force, formerly transferred from the earth to the sun, now turns out to be scattered and disseminated: it is everywhere and nowhere. With the astronomer, we perceive that solar systems are the work of infinitely small bodies; that the power which was supposed to govern the system is itself but the result of the collisions among those infinitely tiny clusters of matter, that the harmony of stellar systems is harmony only ... a resultant of all these numberless movements uniting, completing, equilibrating one another. ${ }^{11}$

Supported by the findings of natural science, Japanese anarchists removed the distinction between high and low, subverted the centrality of the state for human progress, advocated the multiplicity of ever-changing cultures, and promoted voluntary associations for an interdependent world. Mechnikov, who suddenly became a topic of discussion among some prominent Japanese cultural figures following the Russo-Japanese War, is emblematic of the kind of interest in natural science in Japan during this time. Mechnikov discovered the symbiotic functions of the natural world within the human body itself by examining the symbioticinterdependencies of bacteria and other micro-organisms that thrived within the body. For Japanese anarchists, the human body discovered by Mechnikov was a body functioning in mutual interaction and interdependence with its environment from both within and without and was a reflection of the cosmological universe. Mechnikov's understanding of multiple levels of 'social' relations among organisms within and outside the human body led him to reflect in his writings on how an understanding of humans' symbiotic relations with the very microbiotic world within themselves can prolong individual lives. ${ }^{12}$ From the perspective of Japanese anarchists,

11 Peter Kropotkin, Anarchism: Its Philosophy and Ideal, 3rd ed. (San Francisco: Free Society, 1898), 3-4.

12 See Elie Metchnikoff, The Prolongation of Life: Optimistic Studies (London: Heinemann, 1910). Ilia Mechnikov's older brother Lev was a Russian revolutionary and an anarchist who became a wellrecognised scholar of Japanese studies after he travelled to Japan to witness the revolution there in the 1870s. See Sho Konishi, 'Reopening the "Opening of Japan”: A Russian-Japanese Revolutionary Encounter and the Vision of Anarchist Progress', The American Historical Review 112, no. 1 (2007): $101-30$. 
then, interdependent and symbiotic relations from the very internal workings of human beings themselves at the smallest microbiotic level of life negated Malthusian assumptions about the struggle for survival promoted by social Darwinism.

Unlike Freud's urging of a civilisational departure from nature, Mechnikov argued in Nature of Man that the happiness and well-being of man lay in his attainment of harmony with the order of nature that lay both within his own body and without, in his environment. For man's adaptation to nature and harmony with the environment was far from complete, a disjuncture rooted in the profound changes achieved in his evolutionary development, Mechnikov observed. He believed that the exact sciences should serve to remedy the organic disharmonies within humans, thereby offering solutions to the problems of human happiness. ${ }^{13}$

This would be the intellectual foundation of anarchist science that would much later be picked up by the cell biologist Lynn Margulis, one of the most influential biologists in contemporary times. Margulis saw the evolution of cells through the lens of symbiotic dependencies in a similar way to Mechnikov. Prompted by her findings of the symbiotic origins of evolution, Margulis codeveloped the theory of global symbiosis called 'Gaia'. ${ }^{14}$ According to this theory, the earth consists of a self-regulating biosphere dependent on micro-organisms' and plants' unconscious maintenance of the environment in a homeostasis favourable for life. Similar in style of thought, the anti-capitalist conclusions drawn by Margulis herself remind one of the manner in which Japanese anarchists of the early 20th century reflected on Mechnikov's findings about micro-organisms to develop their claims of the relevance of anarchism for human culture and civilisational progress. The controversy prompted by studies of bacteria and other micro-organisms as a dynamic starting point for thinking about the nature of evolution—and 'progress' itself-was as compelling in early 20th-century Japan as it is today.

Through their translations of scientists' writings, anarchists subsequently played a leading role in the popularisation of the natural sciences in Japan in the early 20 th century at large. State officials felt threatened by the massive popularity of anarchist introductions of the biological sciences,

13 See, for example, Elie Metchnikoff, Nature of Man: Studies in Optimistic Philosophy, translated by Sir Peter Chalmers Mitchell (New York: G.P. Putnam's Sons, 1905), 209-15; Metchnikoff, 'The Haunting Terror Of All Human Life', New York Times, 27 February 1910.

14 Lynn Margulis, Symbiotic Planet: A New Look at Evolution (New York: Basic Books, 1998). 
and the government banned their translations of Fabre's entomological study of the dung beetle in Konchū Shakai (Insect Society 昆虫社会). ${ }^{15}$ Fabre's observations of the insect world verified a view of nonhierarchical nature in which each species or form of creature had its own naturally endowed virtue, its own talent, specialised knowledge and ability. Through Fabre's insects, anarchists have helped shape early childhood imagination and perceptions of the natural world. Despite (and sometimes because of) the government's initial ban on translations of Fabre, anarchist translations of his studies of insects in the early 1920s came to capture the national imagination. Even today, Fabre's writings continue to be a sort of 'Mother Goose' of Japan, read by Japanese children as a staple of children's literature and childhood imaginations. The once-banned dung beetle has far outlasted any state regimes and ideologies that banned it, yet our historiography that has focused on the state has silenced the dung beetle from historical memory. If the social knowledge of childhood has the power to order imaginations of the future, then the popularity of anarchists' representations and definition of childhood meant that anarchists had a powerful hand on future visions in Japan, however hidden from history.

The turn to anarchist science on popular grounds interacted discursively with the Western modern construct of civilisational progress. When stripped down to its most basic intellectual foundations, that construct of Western modernity may be most simply understood as a movement away from 'nature' and toward 'culture'. Ishikawa Sanshirō, an anarchist leader and the founder of the influential women's journal Sekai Fujin 世界婦人 with Fukuda Hideko, saw this as the frightening product of the conception of nature as the enemy of civilisation and the antithesis of human culture. He proposed instead to embrace boundless nature, leading to a deep connection of the limited human life to the limitless world of nature. If there were to be any progress in his own life, Ishikawa wrote, that progress was to aim at that idea of a human civilisation deeply interconnected with nature. ${ }^{16}$

15 In English, see Jean Henri Fabre, The Insect World of J. Henri Fabre, trans. Alexander Teixeira De Mattos (New York: Dodd, Mead \& Company, 1949).

16 Ishikawa Sanshirō, Hi shinkaron to jinsei [Non-Evolutionary Theory and Human Life] (Tokyo: Hakuyōsha Shuppan, 1925). 


\section{Cultural Revolution}

Once the concept of nature was redefined, so was the idea of culture. In the roughly 20 years following the Russo-Japanese War, Japanese cooperatist anarchists overturned the meaning of culture and the cultured. By so doing, they provincialised the state to meet the expectations of anarchist progress. I call this reconstruction of the concept of culture an anarchist cultural revolution. This 'revolution' in culture was the product of shifts from high culture to popular, state to non-state, institution to non-institution, sociolinguistic Darwinism to multiplicity and diversity of cultural development, and formal to informal realms of everyday life as the sites, times and sources of cultural expression.

The dualism between the concepts of 'culture' and 'nature' that fed the foundational idea of civilisational progress also disappeared. 'Culture' became the varied, creative expressions of each individual's virtue gifted from nature. Producers of anarchist forms of culture believed that civilisational progress was reliant on these individual expressions for the symbiotic process of social improvement. The anarchist concept of culture thereby inverted both the modern Western notion of civilisation and the ideological foundations of the Japanese imperial state.

A number of distinctive cultural movements and intellectual developments followed one after another to constitute the multifaceted conceptual turns in culture. Such varied expressions and fields of study in early 20thcentury Japan as religion, primatology, microbiology, literature, theatre, popular music, agriculture, language, and children's art and mingei (民芸) folk art responded to the cultural revolution. These cultural expressions were in tune with the formulations of multiplicity, democracy, mutual aid, and symbiosis in scientific nature. The widely recognised and pioneering primatologist Imanishi Kinji, who was fundamentally influenced by 'anarchist science' at this time, developed his influential and radical studies of culture in the primate world — culture in nature-that continue to orient the work of primatologists around the world today. In religion, Tolstoyan anarchist religion was embraced nationwide, leading Tolstoy 
to become the most translated writer in the modern history of Japan. ${ }^{17}$ In folk art, Yanagi Sōetsu, who introduced Mechnikov's microbiology in Japan after the war, would develop the folk art movement called People's Art, Mingei, from this discourse. In 1911, Yanagi had published a wellknown article on Mechnikov, 'Mechnikov's Scientific View on Human Life'. ${ }^{18}$ Yanagi was a member of the White Birch Group that was heavily inspired by its most senior member, Arishima Takeo. Without a conductor to harmonise them, the various cultural expressions nonetheless appeared as if they had been orchestrated to overturn the concept of culture.

Culture was reproduced as knowledge that did not flow from the classrooms of state schools and imperial universities to shape the popular Japanese mind. The production and circulation of knowledge took place instead in unofficial sites of knowledge dissemination and production such as local shrines, rural homes that housed poetry reading groups, churches, village schools, the second floor of the Nakamuraya sweet shop in Tokyo, inns and pubs, the second floor of the Heimin Byoin 平民病院 hospital, pharmacies, the shops and homes of neighbourhood book lenders, dormitories within the imperial universities, and urban 'People’s Cafeterias' (Heimin Shokudo 平民食堂). These cafeterias came to be widely known as Taishū Shokudō (mass cafeterias 大衆食堂), referring here not to the labouring class of Marxist language, but to the anarchist notion of 'everyone' regardless of class. It would be this Taishī, inclusive of everyone, that the so-called 'Marxist' Yamakawa Hitoshi would later call for, as 'Taishiu e' ('v Narod in Russian or 'Going to the People'), using the anarchist concept of the 'people' developed in the course of the Nonwar Movement. People educated themselves and discussed the latest findings in social studies and the natural sciences. Their meetings occurred primarily in the evenings. From day to night, from imperial university campuses to unofficial sites, the places and times where and when the reverse flow of knowledge was developed and disseminated were themselves part of the cultural revolution. ${ }^{19}$

17 For example, Russian scholar Kim Rekho writes, in terms of the breadth and depth of the study of Tolstoy's works, Japan without question occupies a special place among other countries ... Nowhere, except Russia, have the works of Tolstoy been published as many times as in Japan. Nowhere outside Russia have they written about Tolstoy so much as Japan'. Kim Rekho, 'Lev Tolstoi i Vostok' [Lev Tolstoi and the East], in Kim Rekho ed., Lev Tolstoi i literatury Vostoka [Lev Tolstoi and the Literature of the East] (Moscow: IMLI RAN, Nasledie, 2000), 6. Tolstoy's collected works, ranging from 10 to 47 volumes, have been published at least 13 times in Japan.

18 Yanagi Sōetsu, 'Mechinikofu no kagakuteki jinsei kan' [Mechnikov's Scientific View on Life], in his Kagaku to jinsei [Science and Life] (Tokyo: Momiyama Shoten, 1911), 133-326.

19 Konishi, 'Epilogue', Anarchist Modernity, 331. 
Despite the powerful Western origins of the term 'democracy', a notion of anarchist democracy developed in this period without reference to the nation-state. ${ }^{20}$ The Japanese imagination of 'the people' as heimin, without class or national belonging, was the subject for a just democratic sociopolitical order that I have described elsewhere as an invention of the "people" without the state'. The invention of 'the people' as heimin may be compared to the invention of 'the people' in America, which Edmund Morgan demonstrates was integral to American democracy as representative government. ${ }^{21}$ Yet anarchist culture came to define 'the people's practice of everyday democratic life, given expression in such phrases as 'kurashi no chikara 暮らしの力' (the power of everyday life) by the anarchist physician Katō Tokijirō. 'Democracy' for cooperatist anarchists meant the pursuit of the progressive principle of mutual aid in everyday life, a notion outlined by the anarchist Peter Kropotkin in his work Mutual Aid: A Factor of Evolution. ${ }^{22}$ The promise of anarchist democracy, aligned with the notion of progress as ever changing and developing human civilisation, drew numerous people to participate in the expansion of cooperatist anarchism. Their idea of 'democracy' became inseparable from active popular practices of mutual aid to overcome economic hardship. Anarchist democracy became the practical means to solve people's everyday problems and concretely improve their lives in an equitable and mutually beneficial manner through spontaneous associations of people to cooperatively solve shared problems through mutual aid. In this way, cooperatist anarchism gave ideological shape to the development of cooperatist society and sociality, or 'anarchist civil society' if you like.

Anarchists in Japan gave progressive meaning to the everyday cooperative practices of ordinary people, and their corresponding antihierarchical relationality and subjectivity. 'Cooperative living', ranging from the micro-level of everyday life to transnational-scale interdependence between peoples of different ethnicities, races and cultural backgrounds, was identified as the key to achieving democratic society on a global scale.

20 Sho Konishi, 'Translingual World Order: Language Without Culture in Post-Russo-Japanese War Japan', Journal of Asian Studies 72, no. 1 (February 2013).

21 Edmund Morgan, Inventing the People: The Rise of Popular Sovereignty in England and America (New York: W.W. Norton \& Co., 1988).

22 Peter Kropotkin, Mutual Aid: A Factor of Evolution (London: W.W. Heinemann, 1902). 
Functioning within this intellectual universe, Heimin Igaku 平民医学 (The People's Society for Medical Knowledge), Heimin Shokudō (The People's Cafeteria) and Heimin Byöin (The People's Hospital) were founded and supported as cooperative institutions by anarchists to directly address its members' practical needs for hospital treatment, medical knowledge, and meals. In the People's Cafeteria, for example, cafeteria 'regulations' stated that the cafeteria was a 'part of the larger project for Mutual Aid'. This particular people's cafeteria drew on average 700-800 ordinary people every day, with 13,387 people using the cafeteria just in the month of March 1918, for example. ${ }^{23}$ Their spontaneous activities from below to solve real everyday problems on the spot were reminiscent of the popular phrase 'Kayui tokoro ni te ga todoku' (the dexterous hand is able to itch just the right spot かゆいところに手が届く).

Ishikawa Sanshirō coined a new term for this democracy as everyday practice. He created the term 'domin seikatsu 土民生活', or 'the life of people on the soil'. While domin seikatsu stirs up images of farmers tending to the soil, Ishikawa was in fact referring to the organic rootedness of all people in their God-given nature, or virtue. Ishikawa believed that each individual has a will (ishi 意思) or subjectivity/virtue (jitsusei 実性), which was uniquely different in each person. This will, or talent, may be realised only through hard work and the repeated practice of it. Ishikawa called this activity of work and practice 'nenriki 念力', which is the energy or power everyone has to work on and realise their virtue. He called the resulting force that is created in realising one's virtue 'katsudō 活動', or active motion in society. 'Freedom' (jiyzu 自由) was the possibility given to each individual to discover and realise his or her own personal God-given will and virtue. This freedom was the very source of human development, which he called 'sensa banshu 千差万種' (one thousand differences, one million kinds). This realisation of the plurality of individual development, the so-called 'million ways' of participation in the human community, was what Ishikawa meant when he reinvented democracy as 'domin

23 On Katō Tokijiro and the beginnings of these institutions, see Narita Ryūichi, Katō Tokijirō (Tokyo: Fuji Shuppan, 1983). 
seikatsu'. ${ }^{24}$ Ishikawa saw democracy as an expression of what he called the 'new cosmology' defined by the centreless universe. He described the 'unity in multiplicity' that would lead to independence and equality in human society. For Ishikawa, the infinity that characterised our centreless universe dictated the absence of an absolute subject of power and the limitlessness of possibilities for human interaction and cultural invention.

It was in this context that the Esperanto language was named the biggest fad just after the Russo-Japanese War by Asahi newspaper. Once again, the near perfect contrast between the popularity of Esperanto on the ground and the absence of any discussion of Esperantism in the historiography of modern Japan is striking. ${ }^{25}$ The language was studied and discussed by elites and non-elites alike in non-insitutional spaces such as in rural homes, coffee shops, and even on the farm (as occurred in the case of the renowned novelist and social thinker Miyazawa Kenji), often at night when institutions privileged by state and financial power had closed. ${ }^{26}$ By looking at these space-times outside the realms of state guidance, we become privy to an imagination of peace and world order that operated outside the international relations of the nation-state. The history of this cultural-linguistic movement offers us a rare window into a popular concept of world order in Asia. By the mid-1920s, Japan had the highest number of Esperanto speakers by far of any non-European country including the US. Many Esperantists, including leading figures in the anarchist cultural revolution like Ôsugi Sakae, believed that the language, often called 'Minsaigo 民際語', the people's language on the non-state level, in contrast to 'Kokusaigo 国際語' (international language or, literally, 'language between states') as the language of the nation-state

24 Ishikawa Sanshirō, Kinsei domin tetsugaku [Philosophy of Democracy], in Tsurumi Shunsuke ed., Kindai Nihon shisō taikei [Collection of Modern Japanese Thought] 16 (Tokyo: Chikuma Shobō, 1976), 39-111. See also Ishikawa, 'Nōhonshugi to domin shisō' [Agrarianism and Democratic Life], in Ishikawa Sanshirō chosakushū 3 (Tokyo: Seidōsha, 1978), 96-100; 'Shakai bigaku toshite no museifushugi' [Anarchism as Social Aesthetics], in Ishikawa Sanshirō chosakushū 3 (Tokyo: Seidōsha, 1978), 190-206; and 'Dōtai shakai bigaku toshite no museifushugi' [Anarchism as Aesthetic Dynamic], in Ishikawa Sanshirō chosakushū 3 (Tokyo: Seidōsha, 1978), 207-17. See also Kitazawa Fumitake, Ishikawa Sanshirō no shögai to shisō [The Thought and Life of Ishikawa Sanshirō], 3 vols (Tokyo: Hatonomori Shobō, 1974).

25 On the Esperanto movement in the early 20th century as an expression of an understanding of what I call 'translingual world order', see my article, 'Translingual World Order'. On the history of Esperanto in Japan, see also Ian Rapley, 'When Global and Local Culture Meet: Esperanto in 1920s Rural Japan', Language Problems \& Language Planning 37, no. 2 (2013): 179-96. For Rapley's insightful overall treatment of the topic, see his 'Green Star Japan: Language and Internationalism in the Japanese Esperanto Movement, 1905-1944', (DPhil diss., University of Oxford, 2013).

26 Konishi, 'The Science of Symbiosis and Linguistic Democracy'. 
and international relations, was designed to promote the multiplicity of cultures that interdependently coexist and evolve. This distinguished it from the international languages of English or French, for example, that essentially belonged to particular culture(s) and, given power in the context of civilisation discourse of the time, expanded through political, economic and cultural imperialism-'linguistic Darwinism'.

At the heart of anarchist democracy and the modern progress formulated by anarchists were the domestically rooted cooperatist activities found in agrarian communities, the most unlikely place for civilisational progress. Anarchists like Itō Noe identified the cooperatist practices that she observed in her own rural home region to be 'the reality of anarchism in Japan'. Itō saw in those everyday practices a global significance for human progress. She concluded that anarchism has been and continues to exist in everyday practice, and it was therefore this 'reality' that 'we should consciously work on'. ${ }^{27}$

\section{Cooperative Living in Hokkaido}

Let me now turn to the concrete manifestation of these ideas on the most unlikely site, Hokkaido, the experimental site for the realisation of Western modernity in the late 19th and early 20th century. From the first years of the Meiji period, modern agricultural practices were promoted in the vast expanses of Hokkaido as a means to achieve Japan's colonisation of its northern territory and, later, its imperialist expansion into other territories. The farm that had belonged to the father of Shirakaba (White Birch 白樺) Group activist Arishima Takeo was an embodiment of this colonial effort, and Arishima's inheritance of the farm contradicted his anarchist beliefs and practices. He was serving at this time as an unusually popular professor at Hokkaido University where he taught anarchist values in the heart of Japan's colonisation efforts. In distinct polemic with the Japanese Government's modern vision of agriculture modelled after America, Arishima liberated his tenant farmers in 1921, granting them cooperative ownership of the land. He departed from the farm and its affairs entirely upon liberation, believing in the farmers' own abilities to democratically run the farm. Arishima's liberation of

27 Itō Noe, 'Museifushugi no jijitsu' [The Reality of Anarchism], in Itō Noe zenshū [The Complete Works of Itō Noe] 2 (Tokyo: Gakugei Shorin, 1970), 222-35. 
his tenant farmers and founding of a farm cooperatively owned by the farmers on his former estate in Hokkaido in 1921 became a model and symbol of the progressiveness of cooperative practices among rural nonelites. Named Cooperative Living Farm, and widely known as Arishima Farm, the success of the farm was talked about across Hokkaido and well beyond, drawing numerous farmers from across northern Japan to apply for membership. The farm's modern, cooperatist anarchist perception of the world and its integration into the broader agricultural community of Hokkaido suggests that the farm was quite different from the nomadic, self-peripheralised fugitive communites that fled the state, featured in James Scott's anarchist history of Southeast Asia. ${ }^{28}$

The existing view of this famous site of tenant farmer liberation is that of a 'futile utopian project' that failed with Arishima's suicide in 1923. A frequently used Japanese history textbook epitomised this view by describing Arishima's suicide as having 'effectively sealed the fate of this noble but poorly executed experiment'. ${ }^{29}$ Arishima himself, in his liberation speech to the farmers, warned them of the struggles they would face to survive, while 'surrounded by malevolent capitalism'. ${ }^{30}$

In contrast, my interviews with former members of the farm reveal that the farmers themselves felt not only that they were surviving, but that they were at the very forefront of modern progress. ${ }^{31}$ As one member used to say, he felt as if he had 'climbed atop a mountain of jewels' when he and his family became members of the farm. ${ }^{32}$ This sense of achievement and progress came not from concrete material improvement in their lives, of which there was little in the first decades of the farm's existence, but from the shared sense of mutual ownership of the farm and cooperative living in the midst of 'malevolent capitalism'.

28 James C. Scott, The Art of Not Being Governed: An Anarchist History of Upland Southeast Asia (New Haven, CT: Yale University Press, 2009).

29 David Lu, Japan: A Documentary History (Armonk, NY and London, England: M.E. Sharpe, 1997), 400.

30 Arishima Takeo, 'Kosakunin e no kokubetsu' [Farewell to Tenants], Izumi 1 (1 October 1 1922): 43.

31 Sho Konishi, 'Ordinary Farmers, Competing Time: Arishima Cooperative Farm in Hokkaido, 1922-1935', Modern Asian Studies 47, no. 6 (November 2013): 1845-87.

32 A former member of the farm, Kiriyama Katsuo, recalled his father Tokiji saying this to his family and neighbours on numerous occasions. Kiriyama Katsuo, interview by author, Niseko, Japan, 2000. 
As evidenced by the farm's handbook, members interpreted their cooperative farm as the progressive materialisation of anarchist thought on nature, even as their practices relied on common-sense rural traditions of mutual aid interrupted by the expansion of tenant farming. Every member of Cooperative Living Farm carried a copy of the Cooperative Living Handbook. It is the only written document we have from that period. Arishima's liberation speech served as the anchoring centrepiece of the coop book. 'Anyone knows that the source of all production, land, water, air ... should not be owned privately but should be shared and used for the mutual benefit of all human beings. ${ }^{33}$ Along with Arishima, the anarchists Kropotkin and Tolstoy were specifically mentioned as cohorts who shared their ideas of progress based on the principle of Sogo Fujo 相互扶助, Mutual Aid.

The new spaces created by the members of Cooperative Living Farm on the one hand, and their new modern subjectivity of cooperative progress on the other, emerged in reciprocal relation to each other. New spaces created on the farm continuously gave new shape to the community, guiding those who conducted everyday life in those spaces. In tandem with the growing experience of cooperative community-making, these spaces silently gained in sacredness.

The Shintō shrines that dotted the colonial landscape visible atop its farms' highest points have been commonly described as authoritative, patriarchal and forbidding. They were a spatial symbol of colonial control over the lands, which were laid under the shrine's gaze. Behind the gaze were the landlords who built the shrines with the encouragement of the Colonisation Bureau. The shrines represented a masculine patriarchical order that was a foundation for the emperor-centred ideology of the nation-state. The shrines culturally and religiously authenticated settlers' participation in the national colonisation project in Hokkaido. In contrast, Iyateru Shrine of Cooperative Living Farm stood out for its modesty. After Arishima inherited the shrine, he physically removed it from its place atop the farm's highest point on Miya Mountain overseeing the colonial property, to its current position halfway up a small hill, modestly nestled among the other hills of the estate. Following liberation, the shrine became a focal point for community activities, where the farm's annual deliberative meetings, festivals and other community gatherings were

33 Kyōsan nōdan techō [Arishima Cooperative Living Farm Handbook], Arishima Takeo Museum and Archive, Niseko, Japan, 8-7-90. 
held. The farmers themselves further added a new sacred meaning of their own to the shrine. They installed a hidden back window in the shrine, behind which they erected a sacred six-sided stone structure dedicated to the goddesses. When the window was opened for annual ceremonies of cultivation and harvest, it served as a window to the goddesses.

At first glance, the stone appears to be quite similar to numerous pentagonal worship stones erected in the region surrounding the farm to honour the Taishō emperor as a part of State-sponsored Shintōist practices. Many of the stones were erected in the years immediately following the new emperor's enthronement, in 1914-16. ${ }^{34}$ However, close comparison with the many five-sided jijin at other farms in the region reveals that Cooperative Living Farmers erected their stone independently, for the added purpose of paying tribute to their liberation and the founding of the farm.

Members had added an entirely unique sixth side to the traditional five-sided stone of the five goddesses of production. Their hexagonal stone was engraved with the date August 1924, to commemorate the second anniversary of the liberation of the farm and the establishment of their community. The stone thus made it appear as if the emergence of Cooperative Living Farm was being embraced by the five goddesses, inscribed on the remaining five sides. It seemed the goddesses themselves had given birth to Cooperative Living Farm. This was consistent with the farm's shared ideology of the divine nature of the land, which was the deities' 'gift' foundational to the emergence of the community in 1922. The divine givenness of the soil took away the landlord's right to the land. This sixth side was an invention of the Cooperative Living Farmers, who had inserted their realm of cooperative virtue into the sacred realm of the goddesses.

The goddesses of production represented a cosmological foundation of human relations of interdependency with nature, and with other human beings. This most fundamental existence of human beings as they understood it, their dependency on nature and on one another for survival, provided a foundation for their non-hierarchically constituted practices

34 See the works by the local history study group of Kutchan, the neighbouring village of Niseko, Ishida Suteo, Takei Shizuo, and Ono Taizō, Nono shinbutsu [Gods of the Field] (Kutchan: Kutchan Local History Study Group, 1987), and Kutchan chō kyodōbunkazai hozonkai ed., Kutchan no jijinsan batōsan [The Jijinsan and Batōsan of Kutchan] (Kutchan: Kutchan Chō Kyodō Bunkazai Hozonkai, n.d.). 
of mutual aid. The sacred stone stood at the centre of the farm's annual spring planting and fall harvest festivals, which began with ceremonial offerings to the goddesses. The stone thereby further altered the patriarchal authority of the shrine, by reconditioning it with a localised folk religion of the soil. It was as if 'State Shintōism' had never reached here.

Members also erected a water god stone, another unique structure. The stone overlooked and made sacred the farm's dam, which served as the centre point for its irrigation system. Together, the worship stones of water, soil and air completed and concretised the cooperative imperative and delivered the anarchist notion of non-ownership and cooperative utilisation of natural resources for mutual benefit. They represented the foundational ethic of the farm itself, the imperative of shared cultivation and utilisation of the natural resources for the purpose of co-survival with nature.

Technology was neither opposed to nor superior to nature in farm members' understanding. It was seen rather to complement and enhance the gifts of nature. The farm thus vigorously pursued technological advancement. It experimented with some of the latest technological advancements necessary to pipe in water for the paddies. They applied new techniques for temperature moderation of the icy water tapped from the adjacent mountain. ${ }^{35}$ The conversion to rice promised both material and symbolic progress. Back in early Meiji, the Hokkaido Colonisation Office had emphasised the importation of large-scale farming with agricultural technologies from the West that centred on foods like potatoes, corn, beef and dairy. No other farm in the region surrounding Cooperative Living Farm had yet experimented with rice cultivation. The shiny white rice was thus the taste of cooperative living progress. The rice became a part of their identity, as it set the farm apart from the rest of the farms. Within a decade or so, bags of their rice decorated with large red labels 'Arishima mai' [Arishima Rice] were found in stores across the region. Members were convinced of the progressiveness of their existence as a new modern community of mutual aid. Adopting new technologies took considerable place in this progressive self-image. The linkage between

35 Blueprint of the irrigation plan and 'Request to Begin Construction of Irrigation', Arishima Takeo Museum and Archive, 1-6-101. See also Arishima no sato: Arishima nōjō jidai no seikatsu [Arishima's Homeland: Life in Arishima's Farming Period] (Hokkaido). Self-publication in the Arishima Takeo Museum and Archive, 24-7. 
technology and the advancement of cooperative living may be contrasted with surrounding tenant farms, where the benefits of technology were hardly returned to the tenant farmer.

According to former farm member Kiriyama Katsuo, another aspect of their new life on the farm that members had to work on was gift-giving. Kiriyama recalls that members meticulously practised the giving of gifts in carefully measured equal number to each member of the farm. The practice of gift-giving was constructed to horizontalise relations among members of the community. Members consciously contrasted this new practice with the old times of tenancy, when the gift was often used in a vertical bi-directional manner between managers and the labourers who worked for them, functioning to enhance the power relations between them. A gift to the landlord or the manager used to grease the machinery of the tenant-landlord relationship of dependency. Usually given in a single direction to those with power, the gift might anticipate or follow a request for a loan, or some other sort of necessity. It might simply put the tenant in the landlord's favour. In turn, gifts or demonstrations of favour from the landlord served to concretise the benevolent status of the landlord in relation to his tenants. ${ }^{36}$ On Cooperative Living Farm, what might be called the practice of multidirectional gift-giving appears to have functioned as the demonstration of mutual interdependency and the preservation of the non-hierarchy of members' recognition and value to one other. Overall, it helped to dislodge privilege from community relations.

Kiriyama's distinct recollection of his farm's gift-giving practices in interviews revealed members' conscious efforts to habitualise the practice into a new farm tradition. Each family drew on their own particular resources and abilities for simultaneous gift-giving in equal measure. Members looked forward to the deliveries of gifts from multiple directions, and they knew that no more would be given to any particular member

36 Nagatsuka Takashi, The Soil: A Portrait of Rural Life in Meiji Japan, trans. Ann Waswo (London and New York: Routledge, 1989), gives a realistic account of tenant-landlord relations in the early 1900s. On landlord benevolence, see e.g. 39-40. For an anthropological discussion of giftgiving practices in light of psychology and time, see Pierre Bourdieu, Outline of a Theory of Practice (Cambridge: Cambridge University Press, 1977), 3-8. 
than the other. ${ }^{37}$ The power once given to the former 'master' dissipated in the multidirectional material exchange of things. The practice of multidirectional gift-giving was now a practice of 'new' time.

Interestingly, at a time of mass tenant farmer unrest across the country, the All-Hokkaido Agricultural Industrial Cooperative Association also began to speak in the language of cooperatist anarchist, rather than Marxist, progress in the early 1920s. The association was the representative organ for agricultural industrial cooperatives found across Hokkaido, in every town and village. In 1926, the cooperative association published the first issue of its farming journal Kyōei (共栄 Co-prosperity), which outlined the ideals and goals of this large organisation. The journal sought to put the 'world in perspective', to promote thinking among agricultural labourers about world affairs. Situating themselves in a historical time of cooperatist progress, the journal stated that while the 'Great Project' of the Meiji Ishin had fulfilled the political tasks assigned it, the cultural resurrection in modern Japan had not yet been achieved. The declaration of the Hokkaido-wide cooperative called in essence for a second, cultural Ishin, through the 'cooperatist movement'. Farmers themselves were writing history. In accord with the larger History Slide, the cooperative's declaration stated:

In the social life of today's civilisation, we are trying to conduct a life of less anxiety, more pleasure and hope, a life of more creativity, mutual love and mutual aid. Relying on Social Darwinism will never lead to making a society of peace. It is Kropotkinism or Cooperatism that we believe in. To realise this ideal of both the material and spiritual world, sangyo kumiaism (industrial cooperativism) is nothing but Kropotkinism. ${ }^{38}$

Their association represented agricultural practices with anarchist ideas of progress in the very space of Hokkaido, the nation's most intense and complete experimental project of Western modernity, most vividly symbolised by its vast glittering mechanised farms and farming industries. The inversion of Western modernity was now complete.

37 Kiriyama Katsuo, interview by author, Niseko, Japan, 2000. For example, Kiriyama recalled that every year, a family receiving persimmons from relatives on Honshu counted the number of people in each household on the farm and delivered a single fruit for each person in each household. Neighbours came to expect that in the autumn, that household would bring them each a persimmon. The fruits were delivered personally, not losing thereby the cooperative meaning of the gift.

38 'Sangyō kumiai sengen' [Industrial Cooperative Declaration], part I, Kyōei: Hokkaido Sangyō Kumiai zasshi [Coprosperity: Hokkaido Industrial Association Journal] (June 1929): 6-10. 
Tellingly, many years later during the US Occupation of Japan, when American representatives of the Supreme Commander for the Allied Powers (SCAP) came to judge whether Arishima Farm's practices were democratic or not, they couldn't make sense of the farm. This was not 'democracy' as Americans understood it, yet it looked very democratic. Nor was it 'Communist', yet it looked very communal. Giving up on finding a label for it, the Americans left it up to the farmers to decide whether their farm community belonged to the new postwar era.

This particular modernity imagined, lived and experienced by cooperatist anarchists in Japan uprooted and overturned the very state-centred modernity of the West. In this sense, the notions of 'resistance' and 'being overcome by Western modernity' were inadequate to describe this history. By provincialising the state, cooperatist anarchists also naturally provincialised Europe. This was the opposite, I might add, to what postcolonial scholars have attempted to achieve through theories of so-called hybrid cultures and alternative modernities modelled on Western political structures of the state. Even the postcolonial project to 'Provincialise Europe ${ }^{39}$ has in a way re-emphasised the centrality of Western modernity. In contrast, 'survival' in this discourse of cooperatist anarchism, and indeed the survival of this discourse, depended on the successful liberation in both thought and practice from the temporality and the territorial utopia of the modern nation-state of Western modernity. 
This text is taken from New Worlds from Below: Informal life politics and grassroots action in twenty-first-century Northeast Asia, edited by Tessa Morris-Suzuki and Eun Jeong Soh, published 2017 by ANU Press, The Australian National University, Canberra, Australia. 